\title{
DAMPAK KEBIJAKAN AKUNTANSI PEMERINTAH DAERAH ATAS PENERAPAN PERATURAN PEMERINTAH NOMOR 71 TAHUN 2010 DALAM RANGKA PEMBERIAN OPINI ATAS LAPORAN KEUANGAN \\ (Studi Kasus pada Dinas Pendapatan Pengelolaan Keuangan dan Aset Daerah Kabupaten Bolaang Mongondow)
}

\author{
Miftahul Jannah Akuba \\ Jullie J. Sondakh \\ Jantje J. Tinangon
}

(e-mail : miftahulakuba@gmail.com)

\begin{abstract}
The Implementation Government Regulation number 71 year of 2010 about Accrual Based Accounting Standard and The Indonesian Ministry Internal Affairs number 64 year of 2013 about Accounting Policies obligation impact for Local Government to spell the Financial Statements Accounts completely cosinst of presentation, disclosures, measurement, recognition, also used methods in Financial Statements. The Indonesian Ministry Internal Affairs number 64 year of 2013 rules the accounting entity is SKPD must be reported the Financial Statement based accrual to reported entity (DPPKAD) and than report to the BPK. This study aims to determine the extent to which the Accrual Accounting Policies implementation and also to reveal the Problems which in DPPKAD Bolaang Mongondow Regency.

Bolaang Mongondow Regency through DPPKAD has outlined its accounting policies in accordance with the legislation in force through legislation regent Bolaang Mongondow number 12 year of 2014 on accounting policies. Data obtained from the DPPKAD show of 52 SKPD in Bolaang Mongondow Regency, only 6 SKPD reported financial statement to DPPKAD as the reporting entity. The results indicate that the human resources, personal transfers, SPIP weakness, understanding the rules, lack of coordination and leadership are the most decisive factors in the implementation of accounting policies in DPPKAD Bolaang Mongondow District. Then, it unveil a major constraint PPKAD Bolaang Mongondow District offices in describing the accrual-based accounting policies as a key condition of local government financial reporting to the audit board.
\end{abstract}

Keywords : Human resources limitations, high number of personal transfers, SPIP weakness, understanding the rules, lack of coordination and leadership

\subsection{Latar Belakang Masalah}

\section{PENDAHULUAN}

Indonesia baru saja merasakan gegap gempita peralihan dari Sistem Akuntansi Pemerintah berbasis Kas ke Akrual basis. Kenyataan ini tentu berbeda dengan negara-negara lain yang telah terlebih dahulu mengenal maupun menerapkan Sistem ini. Selama lebih dari satu dekade seiring dengan perkembangan akuntabilitas publik yakni pada era tahun 90-an, euforia akrual sudah bukan hal yang asing lagi. Standar Akuntansi Pemerintah berbasis akrual adalah mengakui pendapatan, beban, aset, utang, dan ekuitas dalam pelaporan finansial berbasis akrual serta mengakui pendapatan, belanja, dan pembiayaan dalam pelaporan pelaksanaan anggaran berdasarkan basis yang ditetapkan dalam APBN/APBD. Di Indonesia, untuk pelaporan pelaksanaan anggaran yang ditetapkan oleh pemerintah tersebut adalah berbasis akrual yang sebelumnya ada 4 (empat) yakni Laporan Realisasi Anggaran, Neraca, Laporan Arus Kas, dan Catatan atas Laporan Keuangan. Ke 4 (empat) Laporan Keuangan tersebut kemudian disempurnakan kembali menjadi 7 (tujuh) Laporan Keuangan yakni Laporan Realisasi Anggaran, Laporan Perubahan Saldo Anggaran Lebih, Laporan Operasional, Laporan Perubahan Eekuitas, Neraca, Laporan Arus Kas, dan Catatan atas Laporan Keuangan. Kesemua pelaporan pelaksanaan anggaran tersebut harus diterapkan dan dilaksanakan 
oleh setiap daerah Provinsi/Kabupaten/Kota dengan mengacu pada Peraturan Pemerintah Nomor 71 tahun 2010.

Terkait penerapan Standar Akuntansi Pemerintah Berbasis Akrual sesuai dengan Peraturan Pemerintah Nomor 71 tahun 2010, maka setiap Pemerintah daerah Provinsi/Kabupaten/Kota dianggap perlu untuk menyusun suatu kebijakan akuntansi berbasis akrual. Hal ini dalam rangka untuk mendukung Program Pemerintah berupa SAP berbasis akrual agar sukses dalam penerapannya di daerah. Pemerintah Indonesia menyadari bahwa Laporan Keuangan (financial statement) saat ini menentukan akan keputusan anggaran yang nantinya akan diterapkan sehingga aturan akan kebijakan akuntansi di daerah dianggap perlu untuk ditata mekanismenya. Untuk itulah Pemerintah kembali mengatur Pedoman Kebijakan Akuntansi melalui Permendagri nomor 64 tahun 2013 tentang Penerapan Standar Akuntansi Pemerintah Berbasis Akrual pada Pemerintah Daerah yang pada Lampiran 1 mengatur dengan jelas mengenai panduan penyusunan kebijakan akuntansi pemerintah daerah.

Penyusunan kebijakan akuntansi di daerah adalah murni kewenangan daerah dimana Kepala Daerah adalah pemutus persetujuan produk hukum berupa Peraturan Daerah yang telah melewati prosedur berupa koreksi hingga akhirnya diparaf oleh pejabat berwenang dan mendapat persetujuan oleh Kepala Daerah untuk selanjutnya dilimpahkan ke bagian terkait untuk dilaksanakan. Penyusunan Peraturan Bupati tentang kebijakan akuntansi pemerintah daerah ini dianggap penting mengingat Kabupaten Bolaang Mongondow adalah daerah hasil dari pemekaran. Sudah banyak daerah pemekaran yang membuktikan jika kebijakan akuntansi dijabarkan dengan sebaik-baiknya oleh daerah, maka Opini Wajar Tanpa Pengecualian bukan lagi sekedar impian. Namun faktanya, sejak pemekaran hingga saat ini, Bolaang Mongondow belum pernah sekalipun meraih opini WTP.

Pemerintah Kabupaten Bolaang Mongondow dalam hal ini telah meluncurkan produk hukum daerah berupa Peraturan Bupati Nomor 12 tahun 2014 tentang Kebijakan Akuntansi berbasis akrual. Dimana keseluruhan item kebijakan akuntansi yang diatur dalam Peraturan ini adalah berkiblat pada Peraturan Pemerintah Nomor 71 tahun 2010 yang kembali diatur secara rinci pada Permendagri Nomor 64 tahun 2013. Didalam Peraturan ini, fokus daripada pelaksanaan kebijakan akuntansi terletak pada penyajian, pengungkapan, pengukuran, pengakuan dan metodemetode apa saja yang menjadi pilihan Pemerintah Daerah atas Kebijakan Akuntansi Pelaporan Keuangan dan Kebijakan Akuntansi Akun. Dinas PPKAD Kabupaten Bolaang Mongondow sebagai entitas Pelaporan adalah pelaksana kebijakan akuntansi yang telah diatur oleh Peraturan Bupati Bolaang Mongondow nomor 12 tahun 2014. Dalam hal pelaksanaannya, penerapan item-item kebijakan akuntansi yang telah disentil sebelumnya sejauh ini belum berjalan maksimal namun sudah mengarah pada arah perbaikan yang lebih baik.

Melihat fenomena-fenomena diatas, maka peneliti merasa terpanggil untuk melakukan penelitian yang peneliti beri tajuk "Dampak Kebijakan Akuntansi Pemerintah Daerah atas penerapan Peraturan Pemerintah Nomor 71 tahun 2010 dalam rangka pemberian Opini atas Laporan Keuangan".

\subsection{Rumusan Masalah}

a. Apakah Dinas Pendapatan Pengelolaan Keuangan dan Aset Daerah telah mengikuti dan melaksanakan secara penuh Peraturan Bupati nomor 12 tahun 2014 tentang Kebijakan Akuntansi yang berpedoman pada Peraturan Pemerintah Nomor 71 tahun 2010 dan Permendagri nomor 64 tahun 2013 ?

b. Apakah output/bukti Laporan Keuangan Kabupaten Bolaang Mongondow telah mengikuti Peraturan Pemerintah Nomor 71 tahun 2010 dan Permendagri nomor 64 tahun 2013 ?

c. Apakah kendala atas penerapan Peraturan Bupati Nomor 12 tahun 2014 tentang Kebijakan Akuntansi berbasis akrual?

d. Apakah dampak yang ditimbulkan dari penerapan Kebijakan Akuntansi pada Dinas Pendapatan Pengelolaan Keuangan dan Aset Daerah Pemerintah Daerah Kabupaten Bolaang Mongondow? 
e. Apakah Upaya - upaya yang telah dilaksanakan Dinas Pendapatan Pengelolaan Keuangan dan Aset Daerah Kabupaten Bolaang Mongondow untuk mengatasi kendala-kendala yang mungkin akan dan telah muncul dalam penerapan Peraturan Bupati Nomor 12 tahun 2014 ?

\subsection{Pembatasan masalah}

Berdasarkan rumusan masalah diatas, maka pembatasan masalah penelitian hanya pada lingkup Dinas Pendapatan Pengelolaan Keuangan dan Aset Daerah Kabupaten Bolaang Mongondow berdasarkan pada Peraturan Pemerintah nomor 71 tahun 2010 yang kembali diamanatkan oleh Permendagri nomor 64 tahun 2013, dan disahkan kembali oleh Pemerintah Daerah Kabupaten Bolaang Mongondow melalui Peraturan Bupati Nomor 12 tahun 2014 tentang Kebijakan Akuntansi berbasis akrual serta dampak yang ditimbulkan.

\subsection{Tujuan Penelitian}

Penelitian ini bertujuan :

a. Untuk menganalisis pelaksaanaan kebijakan akuntansi pada Dinas Pendapatan Pengelolaan Keuangan dan Aset Daerah Kabupaten Bolaang Mongondow sesuai dengan Peraturan Bupati nomor 12 tahun 2014 tentang Kebijakan Akuntansi yang berpedoman pada Peraturan Pemerintah Nomor 71 tahun 2010 dan Permendagri nomor 64 tahun 2013.

b. Untuk menganalisis output/bukti Laporan Keuangan Pemerintah Kabupaten Bolaang Mongondow apakah telah mengikuti Peraturan Pemerintah Nomor 71 tahun 2010 dan Permendagri nomor 64 tahun 2013.

c. Untuk menganalisis kendala atas penerapan Peraturan Bupati Nomor 12 tahun 2014 tentang Kebijakan Akuntansi berbasis akrual.

d. Untuk menganalisis dampak yang ditimbulkan dari penerapan Kebijakan Akuntansi pada Dinas Pendapatan Pengelolaan Keuangan dan Aset Daerah Pemerintah Kabupaten Bolaang Mongondow.

e. Untuk menganalisis Upaya - upaya yang telah dilaksanakan Dinas Pendapatan Pengelolaan Keuangan dan Aset Daerah Kabupaten Bolaang Mongondow untuk mengatasi kendalakendala yang mungkin akan dan telah muncul dalam penerapan Peraturan Bupati Nomor 12 tahun 2014.

\subsection{Manfaat Penelitian}
a. Untuk Peneliti
b. Untuk Akademisi
c. Untuk Pemerintah

\subsection{Teori Akuntansi Positif}

\section{TINJAUAN PUSTAKA}

Belkaoui (2007) menjelaskan

“...Dorongan terbesar bagi pendekatatan positif dalam akuntansi adalah untuk menjelaskan dan meramalkan pilihan standar manajemen melalui analisis atas biaya dan manfaat dari pengungkapan keuangan tertentu dalam hubungannya dengan berbagai individu dan pengalokasian sumber daya ekonomi..."

Jensen, M.C (1976) mengungkapkan bahwa perkembangan akan suatu teori akuntansi positif yang nantinya akan menjelaskan mengapa akuntansi seperti apa adanya, sehingga berpengaruh pada yang dimiliki oleh fenomena terhadap penggunaan orang dan sumber daya. Dari pernyataan tersebut dapat ditarik kesimpulan bahwa dalam akuntansi, sumber daya manusia dan sumber daya lainnya adalah hal yang paling berpengaruh. Di dalam Pemerintahan di daerah, penggunaan sumber daya manusia dan sumber daya pendukung lainnya memegang peranan penting untuk menunjang kesuksesan pelaksanaan suatu kebijakan atau sistem yang dilaksanakan

\subsection{Teori Keagenan}

Teori keagenan mendefinisikan hubungan antara prinsipal dan agen yang berakar pada teori ekonomi, teori keputusan, sosiologi dan teori organisasi (DeGeorge, 1992 dikutip oleh Smith \& Bertozzi, 1998). Teori menjelaskan antara pihak (principal) dengan pihak lainnya (agent) dimana 
salah satu pihak berkomitmen dengan pihak lainnya dengan tujuan untuk bertindak seperti yang diinginkan oleh prinsipal yang memiliki kedudukan lebih tinggi.

\subsection{Teori Implementasi Kebijakan}

Pelaksanaan Program Pemerintah Pusat ke Daerah hanyalah omong kosong belaka apabila tidak dibarengi dengan hal-hal yang membuat rentetan program tersebut berhasil.

Pernyataan tersebut lebih jelasnya tergambar pada Standar yang menjadi tolak ukur setiap pemangku implementasi untuk mengambil suatu tindakan. Standar tersebut adalah sebagai berikut :

1. Faktor Komunikasi (Communication)

2. Faktor Sumber Daya (Resources)

3. Faktor Sikap Pelaksana (Disposition)

4. Faktor Struktur Birokrasi (Burreaucratic Structure)

Kelemahan pada Struktur birokrasi adalah faktor penghambat pelaksanaan kebijakan akuntansi di Pemerintah daerah. Bagaimanapun juga pendelegasian tugas oleh Pimpinan ditentukan oleh pola birokrasi yang dilaksanakan. Misalnya saja kebijakan akuntansi diatur melalui Peraturan Daerah. Seorang Bupati memiliki wewenang untuk menentukan pelaksanaan implementasi akan peraturan tersebut dengan mendelegasikan tugas dan tanggung jawab kepada oknum-oknum yang dianggap perlu dan mampu sebagai pelaksana kebijakan tersebut. Hal ini menentukan sukses atau tidaknya pelaksanaan kebijakan tersebut di lapangan.

\subsection{Implikasi bagi Pelaporan Keuangan}

Copeland yang dikutip oleh Belakoui (2007) mengungkapkan dampak dari beragam perubahan akuntansi menunjukkan implikasi-implikasi bagi perencanaan dan pelaporan keuangan diantaranya adalah :

1. Informasi baru yang relevan yang nantinya akan mempengaruhi arus kas di masa mendatang,

2. Informasi yang paling penting yakni memandang masa depan (going concern),

3. Dampak-dampak arus kas yang dilaporkan di dalam neraca, atau di dalam laba rugi, atau dalam catatan kaki tidak akan berdampak buruk sepanjang di umumkan secara umum,

4. Reaksi atas dampak arus kas dan keputusan-keputusan manajemen bukan pada dampak dari laba yang dilaporkan

5. Securities and Exchange Comission (SEC) melaksanakan suatu analisis biaya-manfaat atas seluruh perubahan yang diusulkan dalam pengungkapannya.

\subsection{Pemerintahan Daerah}

Undang-undang No. 32 Tahun 2004 Pasal 1 ayat (2) menyebutkan bahwa Pemerintahan Daerah adalah penyelenggaraan urusan pemerintahan oleh Pemerintah Daerah dan DPRD menurut asas otonomi dan tugas pembantuan dengan prinsip otonomi seluas-luasnya dalam sistem dan prinsip Negara Kesatuan Republik Indonesia sebagaimana dimaksud dalam UUD Negara Republik Indonesia Tahun 1945.

Selain itu juga Undang-undang No. 32 Tahun 2004 Pasal 1 ayat (3) menyebutkan bahwa Pemerintah adalah Gubernur, Bupati atau Walikota, dan perangkat daerah sebagai unsur penyelenggara Pemerintahan Daerah.

Dari penjabaran Undang-undang tersebut dapat diketahui bahwa DPRD, Gubernur, Bupati, Walikota dan perangkat daerah adalah unsur-unsur yang penting dalam hal perumusan kebijakan daerah khususnya pada penerapan Peraturan Pemerintah Nomor 71 tahun 2010 tentang Standar Akuntansi berbasis akrual.

\subsection{Akuntansi Keuangan Daerah}

Akuntansi keuangan daerah adalah berhubungan langsung dengan Sistem Akuntansi Pemerintah Daerah dan dilaksanakan oleh PPK SKPD dalam suatu rangkaian proses yang disebut dengan Siklus Akuntansi Pemerintah Daerah.

Permendagri nomor 64 pasal 6 tahun 2013 menjelaskan bahwa Sistem Akuntansi Pemerintah Daerah dapat dibedakan menjadi 2 (Dua) yakni :

1. Sistem Akuntansi PPKD

2. Sistem Akuntansi SKPD 


\subsection{Standar Akuntansi Pemerintahan}

Peraturan Pemerintah Republik Indonesia nomor 24 tahun 2005 menguraikan bahwa SAP adalah prinsip-prinsip akuntansi yang diterapkan dalam menyusun dan menyajikan Laporan Keuangan Pemerintah. Dengan demikian SAP merupakan persyaratan yang mempunyai kekuatan hukum dalam upaya meningkatkan kualitas laporan keuangan di Indonesia.

\subsection{Standar akuntansi pemerintah berbasis kas menuju akrual (PP No. 24 tahun 2005)}

Dalam kerangka konseptual akuntansi pemerintahan dalam PP 24/2005, basis akuntansi adalah basis kas untuk pengakuan pendapatan, belanja dan pembiayaan dalam Laporan Realisasi Anggaran dan basis akrual untuk pengakuan aset, kewajiban dan ekuitas dalam Neraca. Basis kas untuk Laporan Realisasi Anggaran berarti bahwa pendapatan diakui pada saat kas diterima di rekening kas umum Negara/Daerah atau oleh entitas pelaporan dan belanja diakui pada saat kas dikeluarkan dari rekening kas umum Negara/Daerah atau entitas pelaporan. Basis akrual untuk neraca berarti bahwa aset, kewajiban dan ekuitas dan diakui dan dicatat pada saat terjadinya transaksi, atau pada saat kejadian atau kondisi lingkungan berpengaruh pada keuangan pemerintah, tanpa memperhatikan saat kas atau setara kas diterima atau dibayar. Peraturan Pemerintah nomor 24 tahun 2005 merupakan Standar Akuntansi berbasis kas pertama sebelum diterapkannya Peraturan Pemerintah Nomor 71 tahun 2010 yang memuat tentang Standar Akuntansi Pemerintah berbasis akrual. Kedua basis akuntansi tersebut merupakan bagian dari reformasi akuntansi pemerintahan di Indonesia.

\subsection{Standar akuntansi pemerintah berbasis akrual (PP No. 71 tahun 2010)}

Mahmudi (2011) mengungkapkan isi pokok Standar Akuntansi Pemerintahan mengatur halhal sebagai berikut :

1. Definisi suatu akun

2. Pengakuan suatu transaksi atau akun (recognition)

3. Pengukuran suatu transaksi atas akun tertentu (measurement)

4. Penilaian suatu akun untuk dilaporkan dalam laporan keuangan (valuation)

5. Pelaporan dan pengungkapan (reporting \& Disclosure)

\subsection{Kebijakan Pemerintah}

Anderson yang dikutip oleh Tahir (2014) menyatakan kebijakan adalah suatu tindakan yang mempunyai tujuan yang dilakukan seseorang pelaku atau sejumlah pelaku untuk memecahkan suatu masalah dengan pengklasifikasian kebijakan policy menjadi 2 bagian, yaitu :

1. Kebijakan Substantif yaitu apa yang harus dikerjakan oleh pemerintah.

2. Kebijakan prosedural yaitu siapa dan bagaimana kebijakan tersebut diselenggarakan.

Dengan kata lain, kebijakan pemerintah adalah kebijakan-kebijakan publik yang dikembangkan oleh badan-badan dan pejabat pemerintah.

\subsection{Kebijakan Akuntansi}

Kebijakan akuntansi yang telah diatur melalui Peraturan Bupati memerlukan komitmen dalam pelaksanaannya. Dinas PPKAD sebagai entitas akuntansi adalah pelaksana utama kebijakan akuntansi di Pemerintah Daerah.

Erlina (2015) yang menjelaskan beberapa kebijakan akuntansi penting adalah meliputi sebagai berikut :

1. Entitas pelaporan;

2. Basis akuntansi yang mendasari penyusunan laporan keuangan;

3. Basis pengukuran yang digunakan dalam penyusunan laporan keuangan;

4. Kesesuaian kebijakan-kebijakan akuntansi yang diterapkan dengan ketentuan-ketentuan pernyataan Standar Akuntansi Pemerintah oleh suatu entitas pelaporan, dan

5. Setiap kebijakan akuntansi tertentu yang diperlukan untuk memahami laporan keuangan.

\subsection{Kebijakan Akuntansi menurut Permendagri Nomor 64 tahun 2013}

1. Penyusunan Kebijakan Akuntansi Pelaporan Keuangan.

Penyusunan Kebijakan Akuntansi Pelaporan Keuangan merujuk padaLampiran satu Peraturan Pemerintah Nomor 71 tahun 2010 tentang Standar Akuntansi Pemerintahan, khususnya :

1) PSAP 01 tentang Penyajian Laporan Keuangan 
2) PSAP 02 tentang Laporan Realisasi Anggaran

3) PSAP 03 tentang Laporan Arus Kas

4) PSAP 04 tentang Catatan Atas Laporan Keuangan

5) PSAP 11 tentang Laporan Keuangan Konsolidasian

6) PSAP 12 tentang Laporan Operasional, dan

7) IPSAP dan Buletin Teknis SAP terkait pelaporan keuangan

2. Penyusunan Kebijakan Akuntansi Akun

Adapun tahapan penyusunan kebijakan akuntansi terkait akun diawali dengan mempelajari SAP khususnya pernyataan terkait akun-akun. Penyusunan kebijakan Akuntansi Akun masih merujuk pada Lampiran satu Peraturan Pemerintah Nomor 71 tahun 2010 tentang Standar Akuntansi Pemerintahan khususnya mengatur tentang :

1) PSAP 05 tentang Akuntansi Persediaan

2) PSAP 06 tentang Akuntansi Investasi

3) PSAP 07 tentang Akuntansi Aset Tetap

4) PSAP 08 tentang Akuntansi Konstruksi dalam Pengerjaan

5) PSAP 09 tentang Akuntansi Kewajiban

6) PSAP 10 tentang Koreksi kesalahan, Perubahan Kebijakan Akuntansi, Perubahan Estimasi Akuntansi, dan Operasi yang tidak dilanjutkan

7) IPSAP dan Buletin Teknis SAP terkait akun

\subsection{Kebijakan Akuntansi Pemerintah Daerah berdasarkan Peraturan Bupati Nomor 12} tahun 2014

Peraturan Bupati Nomor 12 tahun 2014 tentang Kebijakan Akuntansi telah mengungkapkan bahwa Kebijakan Akuntansi terdiri atas dua yakni Kebijakan Akuntansi Pelaporan Keuangan dan Kebijakan Akuntansi Akun.

1. Kebijakan Akuntansi Pelaporan Keuangan terdiri dari :

1) Kerangka Konseptual Kebijakan Akuntansi Pemerintah Daerah

2) Penyajian Laporan Keuangan

3) Laporan Realisasi Anggaran (LRA)

4) Laporan Perubahan Sisa Anggaran Lebih (LPSAL)

5) Neraca

6) Laporan Operasional (LO)

7) Laporan Arus Kas

8) Laporan Perubahan Ekuitas (LPE)

9) Catatan atas Laporan Keuangan

2. Untuk Kebijakan Akuntansi Akun terdiri atas :

1) Akuntansi Aset

2) Akuntansi Kewajiban

3) Akuntansi Ekuitas

4) Akuntansi Pendapatan-LO dan Pendapatan-LRA

5) Akuntansi Beban dan Belanja

6) Akuntansi Transfer

7) Akuntansi Pembiayaan

8) Akuntansi atas Koreksi Kesalahan, Perubahan Kebijakan Akuntansi, Perubahan Estimasi Akuntansi, dan Operasi yang tidak dilanjutkan

\subsection{Dampak Penerapan Kebijakan}

Dapat juga diungkapkan bahwa suatu penerapan kebijakan dapat membawa akibat atas negosiasi atau proses tawar menawar dalam rangka merumuskan isu-isu dan metode implementasi yang digunakan. Hal ini senada jika dikaitkan dengan kebijakan akuntansi yang diatur oleh pemerintah, dimana akibat yang ditimbulkan adalah menjawab isu - isu atas pengungkapan (disclosures), serta metode metode apa saja yang digunakan dalam melaksanakan kebijakan akuntansi atas Standar Akuntansi Pemerintah yang telah ditentukan dalam hal ini Peraturan Pemerintah Nomor 71 tahun 2010. 


\subsection{Sistem Pengendalian Interen yang efektif}

Menurut Peraturan Pemerintah Nomor 60 tahun 2008 tentang Sistem Pengendalian Interen Pemerintah Bab II menjelaskan bahwa terdapat Lima unsur Sistem Pengendalian Interen yang terdiri atas:

1. Lingkungan pengendalian;

2. Penilaian risiko;

3. Kegiatan pengendalian;

4. Informasi dan komunikasi; dan

5. Pemantauan pengendalian intern.

Penerapan unsur SPIP sebagaimana dimaksud tersebut dilaksanakan menyatu dan menjadi bagian integral dari kegiatan Instansi Pemerintah termasuk dalam hal ini kegiatan penerapan atas peraturan Bupati nomor 12 tahun 2014 tentang kebijakan akuntansi.

\subsection{Penelitian Terdahulu}

Rozaidy Mahadi, Raman Noordin, Rasid Mail and Kaziemah Sariman. (2014) telah meneliti tentang penerapan akrual basis sektor publik di New Zealand Australia dan United Kingdom dengan judul penelitian Accrual Accounting in Malaysia: What We Should Learn from Others. Hasil penelitian menunjukkan akrual basis memiliki sejumlah kesulitan dalam penerapannya khususnya dalam penyajian aset dan hutang. Hal ini disebabkan atas sistem akrual itu sendiri membutuhkan ketelitian dalam pelaksanaannya.

Babutunde, Shakirat Adepeju. (2013) telah meneliti tentang dampak dari transisi penganggaran akrual basis dalam rangka akuntabilitas dan transparansi pada publik sektor di Nigeria dengan judul penelitian The Effects Of Adoption Of Accrual-Based Budgeting on Transparency and Accountability in The Nigerian Public Sector. Hasil penelitian mengindikasikan dampak yang signifikan dari akuntabilitas dan transparansi anggaran dalam pertumbuhan ekonomi di publik sektor Nigeria.

Agbodike, F.C \& Udunze, U.M. (2014), telah meneliti indikasi yang ditimbulkan dari akuntabilitas dan efektifitas pelaporan keuangan di Pemerintah Daerah Anambra Nigeria dengan judul penelitian Factors Militating Against Financial Accountability and Effective Stores Control in Local Government Areas in Anambra State, Nigeria. Dari 2.803 pekerja di Anambra, diambil 280 sampel pekerja. Penelitian menyimpulkan bahwa akuntabilitas, pengendalian, efektifitas, managemen, dan sumber daya sebagai faktor yang paling berpengaruh pada akuntabilitas laporan keuangan di Anambra Nigeria.

\section{KERANGKA KONSEPTUAL}

1.

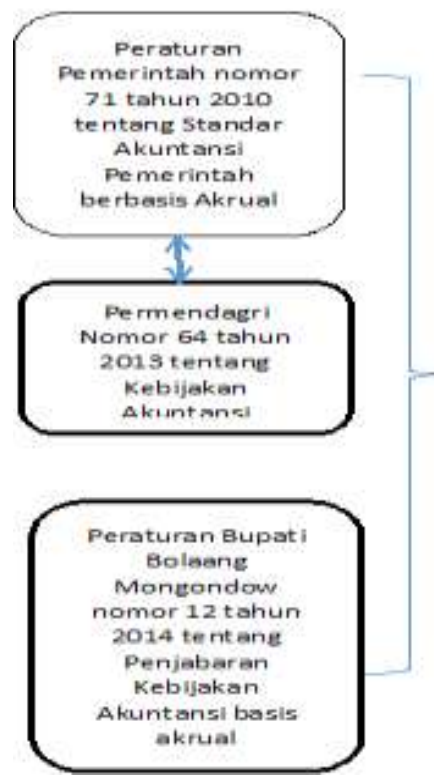

Kebijakan
Akuntansi
Pelaporan
Keuangan
- LRA
- LPSAL
- Neraca
- LO
- LAK
- LPE
- CALK
Kebijakan
Akuntansi
Akun
- Definisi,
- Peneakuan
- Pengukuran
- Penilaian
- Pergungkapa
n
Metode
Akuntansi
- Pengaturan
lebih rinci
atas SAP

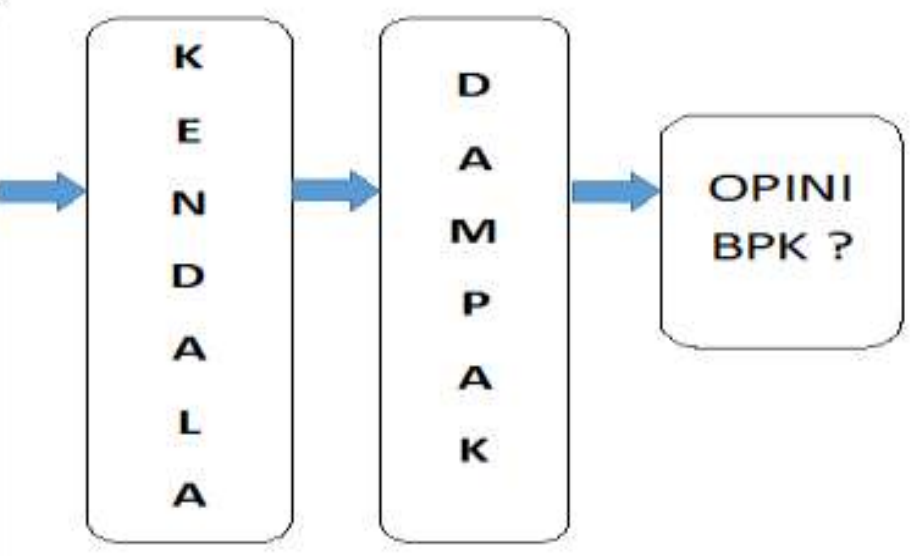




\subsection{Pendekatan Penelitian}

\section{METODE PENELITIAN}

Penelitian ini menggunakan penelitian pendekatan kualitatif. Menurut Djam'an Satori dan Aan Komariah (2013) penelitian kualitatif adalah mengembangkan pertanyaan dasar tentang apa dan bagaimana kejadian itu terjadi, siapa yang terlibat dalam kejadian tersebut, kapan terjadinya dan dimana tempat kejadiannya.

Penelitian kualitatif dilakukan karena peneliti ingin mengeksplor fenomena-fenomena yang tidak dapat dikuantifikasikan yang bersifat deskriptif .

\subsection{Objek Penelitian}

Adapun Objek penelitian ini adalah Bupati Bolaang Mongondow, Sekretaris Daerah Kabupaten Bolaang Mongondow, Kepala Dinas PPKAD Kabupaten Bolaang Mongondow, dan Kabid Akuntansi Dinas PPKAD Kabupaten Bolaang Mongondow.

\subsection{Teknik Pengumpulan Data}

Dalam penelitian ini, peneliti menggunakan 3 (Tiga) teknik pengumpulan data, yaitu :

1. Studi Pustaka

2. Observasi

3. Wawancara mendalam (In-depth Interview)

\subsection{Alat Bantu pengumpulan Data}

1. Pedoman wawancara

2. Pedoman Observasi

3. Alat Perekam

\subsection{Keabsahan Penelitian}

Penelitian ini menggunakan pendekatan kualitatif. Djam'an Satori dan Aan Komariah (2013) menjelaskan suatu penelitian kualitatif dinyatakan absah apabila memiliki 4 (Empat) hal yakni sebagai berikut :

Keterpercayaan (Credibility/Validitas Internal), Keteralihan (Transferability/validitas eksternal), Kebergantungan (Dependability/Reliabilitas), Kepastian (Confirmability/Objectivitas)

\subsection{Lokasi dan Waktu Penelitian}

Penelitian dilakukan di Kantor DPPKAD Kabupaten Bolaang Mongondow, sementara untuk waktu penelitian berlangsung selama 3 (tiga) bulan, yakni mulai bulan Juni 2016 sampai dengan bulan Agustus 2016.

\subsection{Teknik Analisis Data}

Adapun model tahapan analisis menurut Burhan Bungin (2011) adalah analisis induktif yakni sebagai berikut :

1. Melakukan pengamatan terhadap fenomena sosial, melakukan indentifikasi, revisi-revisi, dan pengecekan ulang terhadap data yang ada

2. Melakukan kategorisasi terhadap informasi yang diperoleh

3. Menelusuri dan menjelaskan kategorisasi

4. Menjelaskan hubungan-hubungan kategorisasi

5. Menarik kesimpulan-kesimpulan umum

6. Membangun atau menjelaskan teori.

\section{HASIL PENELITIAN}

Hasil penelitian menunjukkan Pemerintah Kabupaten Bolaang Mongondow melalui Dinas PPKAD Kabupaten Bolaang Mongondow telah melaksanakan kebijakan akuntansi berbasis akrual berdasarkan Peraturan Bupati nomor 12 tahun 2014 sesuai dengan amanat Peraturan Pemerintah nomor 71 tahun 2010 dan Permendagri nomor 64 tahun 2013. Adapun pelaksanaan kebijakan akuntansi meliputi penyajian, pengungkapan, pengukuran dan metode-metode yang digunakan dalam penjabaran kebijakan akuntansi yang dibutuhkan oleh Pemerintah Daerah Kabupaten Bolaang Mongondow. Berdasarkan informasi yang dikemukakan oleh para Informan kunci terkuak bahwa Penyajian aset pada SIMDA Dinas Pendapatan Pengelolaan Keuangan dan Aset Daerah Kabupaten Bolaang Mongondow belum memadai. Sebagai contoh pada Neraca Pemerintah Daerah 
Kabupaten Bolaang Mongondow terdiri atas Tagihan jangka panjang, kemitraan dengan pihak ketiga, aset tak berwujud dan aset lain-lain. Dari keseluruhan aset lainnya, aset lain-lain adalah Rp. 118.598.228.479,58. Kabid Akuntansi mengkonfirmasi bahwa aset lain-lain terbentuk dari aset tetap yang belum terjabarkan pada Aset Tetap. Tidak terjabarkannya aset sesuai klasifikasi merupakan penyebab utama Kabupaten Bolaang Mongondow belum meraih WTP pada tahun anggaran 2015.

Selain itu hasil penelitian mengerucut pada kendala-kendala dalam pelaksanaan kebijakan akuntansi tersebut serta dampak yang ditimbulkan. Adapun kendala yang muncul dalam pelaksanaan kebijakan akuntansi terurai dalam tabel berikut ini.

Tabel 5.5 Uraian Kendala dan Penyebab Pelaksanaan Kebijakan Akuntansi menurut Permendagri nomor 64 tahun 2013 dengan Peraturan Bupati Bolaang Mongondow nomor 12 tahun 2014 Dinas Pendapatan Pengelolaan Keuangan dan Aset Daerah Pemerintah Daerah Kabupaten Bolaang Mongondow

\begin{tabular}{|c|c|c|c|c|}
\hline \multirow[t]{2}{*}{ No } & \multirow{2}{*}{$\begin{array}{c}\text { Deskripsi } \\
\text { (BolMong menuju } \\
\text { Opini yang lebih baik) }\end{array}$} & \multicolumn{2}{|c|}{ Hasil Penelitian } & \multirow{2}{*}{$\begin{array}{c}\text { Dampak Kebijakan Akuntansi } \\
\text { Pemerintah Daerah } \\
\text { Kabupaten Bolaang } \\
\text { Mongondow }\end{array}$} \\
\hline & & Kendala & Penyebab & \\
\hline 1 & 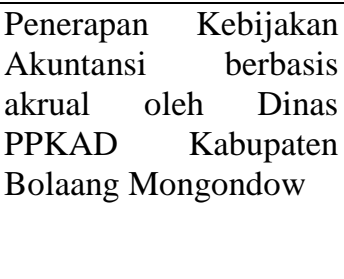 & $\begin{array}{l}\text { Penyajian Aset dalam } \\
\text { Laporan Keuangan } \\
\text { Neraca PPKAD. }\end{array}$ & 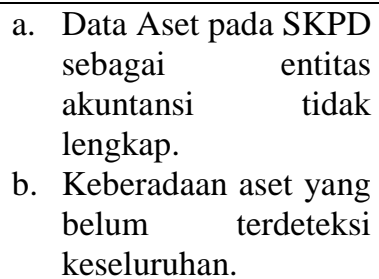 & 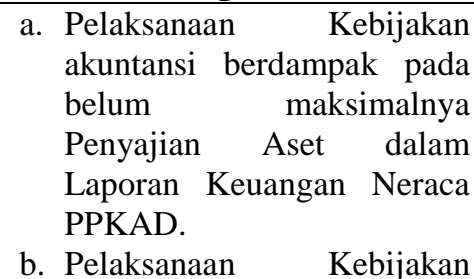 \\
\hline 2 & & $\begin{array}{l}\text { SIMDA SKPD tidak } \\
\text { berjalan sebagaimana } \\
\text { mestinya. }\end{array}$ & $\begin{array}{l}\text { a. Kompetensi Sumber } \\
\text { Daya Manusia } \\
\text { b. Belum Optimalnya } \\
\text { Sosialisasi dan } \\
\text { Bimtek oleh Dinas } \\
\text { PPKAD sebagai } \\
\text { entitas pelaporan } \\
\text { c. Tingginya insentitas } \\
\text { Mutasi ASN di } \\
\text { lingkungan SKPD. } \\
\text { d. Anggaran tidak } \\
\text { memadai. }\end{array}$ & $\begin{array}{l}\text { Akuntansi berdampak pada } \\
\text { tidak terlaksananya SIMDA } \\
\text { SKPD. } \\
\text { c. Pelaksanaan Kebijakan } \\
\text { Akuntansi menyebabkan } \\
\text { SKPD sebagai entitas } \\
\text { akuntansi tidak memasukan } \\
\text { Laporan Keuangan berbasis } \\
\text { akrual. }\end{array}$ \\
\hline 3 & & $\begin{array}{lr}\text { SKPD } & \text { tidak } \\
\text { memasukan } & \text { Laporan } \\
\text { Keuangan } & \text { berbasis } \\
\text { akrual. } & \end{array}$ & $\begin{array}{l}\text { a. Kelemahan } \\
\text { Leadership } \\
\text { b. Lemahnya tingkat } \\
\text { pemahaman aturan } \\
\text { c. Lemahnya SPIP }\end{array}$ & \\
\hline 4 & & $\begin{array}{l}\text { Server Online akses } \\
\text { SIMDA ke SKPD } \\
\text { belum tersedia }\end{array}$ & $\begin{array}{l}\text { a. Keterbatasan } \\
\text { anggaran }\end{array}$ & \\
\hline
\end{tabular}

Sumber : Hasil olah data, 2016

\subsection{KESIMPULAN}

\section{KESIMPULAN DAN SARAN}

Atas dasar fenomena-fenomena yang telah Peneliti teliti dan analisa, maka Peneliti mengklasifikasikan hal-hal berikut untuk dapat disimpulkan melalui kesimpulan penelitian sebagai berikut :

1. Dinas PPKAD sebagai entitas pelaporan telah sepenuhnya melaksanakan Kebijakan Akuntansi sebagai syarat utama dalam Pelaporan Keuangan di BPK.

2. SKPD sebagai entitas akuntansi belum sepenuhnya melaksanakan kebijakan Akuntansi melalui Laporan Keuangan SKPD. 
3. Belum memadainya tingkat kompetensi Sumber Daya Manusia, inisiatif pengelola keuangan dari SKPD, tingkat pemahaman SDM pengelola keuangan SKPD atas aturan mengenai Standar Akuntansi Pemerintah berbasis akrual, klasifikasi aset yang dilaksanakan oleh SKPD dan Dinas PPKAD.

\subsection{Rekomendasi}

1. Peningkatan anggaran dalam rangka pembiayaan Bimbingan Teknis, Sosialisasi, Perjalanan Dinas dalam daerah (khusus untuk penagihan, pelacakan aset yang belum terdeteksi), peningkatan sarana dan prasarana serta anggaran untuk pembangunan server jaringan SIMDA di DPPKAD Kabupaten Bolaang Mongondow.

2. Peningkatan kualitas Sumber Daya Manusia di bidang Pengelolaan Keuangan Daerah dengan cara menggalakkan Bimbingan Teknis, dan Sosialisasi.

3. Peningkatan koordinasi secara berkala antara Dinas PPKAD sebagai entitas pelaporan dan SKPD sebagai entitas akuntansi dalam hal mendskusikan kendala - kendala pelaksanaan pelaporan Laporan Keuangan di Dinas-Dinas.

\subsection{Keterbatasan Penelitian}

Penelitian ini bukanlah suatu penelitian yang sempurna dimana masih memiliki berbagai keterbatasan.

1. Penelitian yang dilakukan terbatas pada lingkup Dinas Pendapatan Pengelolaan Keuangan dan Aset Daerah Kabupaten Bolaang Mongondow berdasarkan pada Peraturan Pemerintah nomor 71 tahun 2010 yang kembali diamanatkan oleh Permendagri nomor 64 tahun 2013, dan disahkan kembali oleh Pemerintah Daerah Kabupaten Bolaang Mongondow melalui Peraturan Bupati Nomor 12 tahun 2014 tentang Kebijakan Akuntansi berbasis akrual serta dampak yang ditimbulkan.

2. Penelitian yang dilakukan menggunakan metode deskriptif kualitatif dengan triangulation data.

\section{DAFTAR PUSTAKA}

Agbodike, F.C \& Udunze, U.M. 2014, Factors Militating Against Financial Accountability and Effective Stores Control in Local Government Areas in Anambra State, Nigeria (20032011), Review of Public Administration and Management Vol. 3, No. 6, December 2014

Babutunde, Shakirat Adepeju. 2013, The Effects Of Adoption Of Accrual-Based Budgeting on Transparency and Accountability in The Nigerian Public Sector. International Journal of Governmental Financial Management - Vol.XIII, No.1, 2013

Badan Pusat Statistik Bolaang Mongondow. 2011. Bolaang Mongondow dalam Angka. BPS Belkaoui, A.Riahi. 2007. Accounting Theory. Jakarta:Salemba Empat

Bungin, Burhan. 2011, Penelitian Kualitatif, Komunikasi, Ekonomi, Kebijakan Publik, dan Ilmu Sosial Lainnya. Jakarta : Prenadia Media Group

Djam'an Satori \& Aan Komariah . 2013. Metodologi Penelitian Kualitatif. Bandung : CV Alfabeta Hartati Yenni. 2011, Analisa Pengungkapan Laporan Keuangan Opini Wajar Tanpa Pengecualian IPSASb. 2013. International Public Sector Accounting Standards Board - First Time Adoption of Accrual Basis International Public Sector Accounting Standards (IPSASs)

Jensen, M.C. 1976. Reflections on the State of Accounting Research and the Regulation of Accounting

Mahmudi. 2011. Akuntansi Sektor Publik. Yogyakarta : Yogyakarta : UII Press

Mursyidi. 2013, Akuntansi Pemerintahan di Indonesia. Bandung : PT Refika Aditama

Peraturan Pemerintah. 2005. Standar Akuntansi Pemerintahan Cash towards Accrual. No. 24

Peraturan Pemerintah. 2010. Standar Akuntansi Pemerintah Berbasis Akrual. No. 71

Peraturan Pemerintah Nomor 60 tahun 2013 tentang Sistem Pengendalian Interen Pemerintah

Peraturan Bupati Bolaang Mongondow No. 12 tahun 2014 tentang Kebijakan Akuntansi Pemerintah Berbasis Akrual.

Peraturan Bupati Bolaang Mongondow nomor 34 tahun 2009 tentang Uraian Tugas Dinas Pendapatan Pengelolaan Keuangan dan Aset Daerah Kabupaten Bolaang Mongondow 
Rozaidy Mahadi, Raman Noordin, Rasid Mail and Kaziemah Sariman. 2014, Faculty of Business, Economics and Accountancy, Universiti Malaysia Sabah, Accrual Accounting in Malaysia : What We Should Learn from Others. Malaysian Journal of Business and Economics Vol.1, No,2 December 2014 63-76

Sugiyono, 2014. Metode Penelitian Kuantitatif, Kualitatif dan R\&D. Bandung: Alfabeta

Smith, W. Robert and Mark Bertozzi. 1998. Principals and Agents : An explanatory model of public budgeting. Journal of Public Budgeting and Financial Management (Fall) : 325-353

Tahir, Arifin. 2014, Kebijakan Publik \& Transparansi Penyelenggaraan Pemerintah Daerah. Bandung : Alfabeta, cv

Undang-undang No. 1 tahun 2004 tentang Perbendaharaan Negara

Undang-undang No. 15 tahun 2004 tentang Pemeriksaan Pengelolaan dan Tanggung Jawab Keuangan Negara

Undang-undang No. 17 tahun 2003 tentang Keuangan Negara.

Undang-undang No. 32 Tahun 2004 tentang Pemerintahan Daerah 